\title{
Reducing Sultani Figs Losses During Markeeting by Thymol and Chitosan Dipping
}

\author{
Mostafa, Y.S. ${ }^{1}$, I.M. El-Berry ${ }^{1}$ and N.S. Mustafa ${ }^{2}$ \\ ${ }^{1}$ Department of Pomology, Faculty of Agriculture, Alexandria University, Alexandria, Egypt \\ ${ }^{2}$ Department of Pomology, National Research Center, Dokki, Giza, Egypt
}

\begin{abstract}
The aim of this study was to evaluate the effect of chitosan and thymol postharvest dipping on maintaining fruit quality attributes of Sultani figs. Ripe fig fruits gently picked manually and treated with 0.3 or $0.6 \mathrm{mM}$ thymol and 2.5 or $5 \mathrm{~g} / \mathrm{L}$ chitosan in addition to water treatment then stored at $0^{\circ} \mathrm{C}$ and 85-90\% RH. A Samples of stored fruits were taken every week to estimate determine fruit quality and storability. The results of the study showed that chitosan treatments significantly reduced fruit weight loss and shriveling percent up to three weeks as compared with the untreated fruit. Thymol and chitosan treatments decreases the percentage of decay incidence and quantitative losses after one, two or three weeks of cold storage plus two days at room temperature especially at the high concentration. All treatments caused a decrease in the percentage of quantitative losses after two or three weeks of storage as compared to control and $0.3 \mathrm{mM}$ thymol. Chitosan significantly maintained fruit firmness, SSC, total and non-reducing sugars up to 3 weeks. In addition, thymol and chitosan treatments had higher phenolic content than control after 1 or two weeks.
\end{abstract}

Keywords: Fig- safe agrochemicals -postharvest - quality.

\section{INTRODUCTION}

The common fruit figs (Ficus carica L.), are one of the highest nutritious fruits, rich in sugars, potassium, calcium, iron and dietary fiber. It is also important source of vitamins, amino acids and antioxidants, in addition it is sodium, fat and cholesterol free (Slavin, 2006 and Veberic et al., 2008). Egypt are the second major producer of figs after Turkey, with cultivated area 28,617 ha and annual production 177, 135 tonnes (FAO, 2017). Shelf-life of fresh fig is extremely short, lasting 1-2 day at $20{ }^{\circ} \mathrm{C}$ (Morton, 2000). Fresh ripe figs are soft, delicate, easily bruised and very susceptible to decay. Postharvest phyto-pathological diseases severely limited the storagability. Thus, it commonly consumed near to the production area. So, the reduction of postharvest losses and prolong the storage life will led to developing global marketing.

The major fig diseases are alternaria rot caused by (Alternaria spp.), gray mold (Botrytis cinerea), fig endosepsis (Fusarium spp.) and sour rot (Doster et al., 1996; Doster and Michailides, 2007; Coviello et al., 2009). Several postharvest practices of fresh figs were applied to control decay development during storage and marketing. Controlled atmosphere (CA) at 5\%-10\% $\mathrm{O}_{2}$ and $15 \%-20 \%$ $\mathrm{CO}_{2}$ is useful for reduction of figs rot and increase postharvest life. But long storage in CA led to a loss of figs flavor (Crisosto and Kader, 2007). Also acetaldehyde increased of 'Mission' figstreated with high $\mathrm{CO}_{2}$ during the first week, followed by a slight increase of ethanol content which result in developing off-flavor (Colelli et al., 1991). Moreover, the postharvest use of $\mathrm{SO}_{2}$ before or during cold storage showed a significant reduce of decay percent of fresh figs during shelf-life. On the other hand, many restrictions face continues use of $\mathrm{SO}_{2}$ due to higher residual level, in addition to its bleaching effect on fruit color (Crisosto et al. 2007).

For thus, an efficient safe alternativeis seriously needed to control postharvest decay development on fresh figs. Biological practices against postharvest pathogens of fruit include the use of microbial antagonists, natural compounds, or inducers of resistance active on the host (Spadaro and Gullino, 2014). Postharvest dipping treatments in hot water and sodium carbonate can be used to reduce decay percent for 1 or 2 weeks maximum (Molinu et al., 2006). Also, essential oils are natural antioxidants, well known for their antimicrobial and biodegradable properties, safe/low toxic and nonresidual compound for humans and the environment (Kalemba and Kunicka, 2003). The potential of using essential oils and their derivatives to control the postharvest diseases has been investigated in many fresh fruits. Thymol as essential oil from thyme is listed by U.S. Food and Drug Administration as food for human, and it has been used as food preservative, additives and medicinal drug (Jain, 1985; Mansour et al., 1986). Liu et al. (2002) reported that postharvest thymol treatment markedly reduced the germination of Monilinia fructicola conidia to $2 \%$ compared with $98 \%$ on untreated apricot fruit. Also, thymol was highly efficient in controlling gray mold on sweet cherries (Chu et al., 1999) and strawberry (Geransayeh et al., 2015).

In addition, the postharvest treatments with chitosan has been suggested due to its antimicrobial effect on several plant diseases, it is also conceded as safe edible coating material and environment safe 
(Tripathi and Dubey, 2004). A semi-permeable film can be formed on fruit treated with chitosan, which might be modify the internal atmosphere, as well as to decrease water losses and maintain the quality of the fruits (Olivasand Barbosa-Ca'novas, 2005). Chitosan has broad-spectrum antimicrobial ctivity, which has been well documented (AitBarka, et al., 2004). Application of chitosan has been shown to be effective for control of postharvest diseases and prolonged the storage lifein various fruit such as table grapes, strawberry and jujube fruits without negative effect on fruit quality (El Ghaough et al.,1992; Romanazzi et al.,2002; Meng et al., 2008; Wang et al., 2014).

From the previous studies which refers to the significant effect of thymol as an essential oil and chitosan on reduction of postharvest diseases, they may be promising to manage the decay incidence and losses of fresh figs. The objective of this study was to investigate the effects of postharvest dipping treatments with thymol and chitosan on fruit quality, postharvest life and quantitative losses during cold storage of at $0^{\circ} \mathrm{C}$ and $85-90 \% \mathrm{RH}$.

\section{MATERIALS AND METHODS}

\section{Plant materials, treatments and statistical design}

This experiment was conducted during2017 and 2018 seasons on Sultani fig (Ficus carica L.). Fresh fig fruits were manually harvested at ripe stage from 8-year-old trees, grown in a private orchard in Sedi Abdel-rahman, Matrouh governorate, Egypt. Harvested Figs gently packed in carton boxes $(2 \mathrm{~kg})$ in two layers, and directly transported to the postharvest laboratory at Faculty of Agriculture, Alexandria University.

The fruits carefully sorted to get rid of unsuitable fruits (mechanical injured, over-ripe, unripe, deformed), uniform fruits ripe stage, size, color and shape were selected to conduct this experiment. The selected fruits were divided into sixty experimental units $(5$ treatments $\mathrm{x} 3$ replicates x 4 sampling times). Each experimental unitconsisted of $3 \mathrm{~kg}$ fruits. Twelve experimental units were randomly selected and subjected for one of the following dipping treatments for one minutes; untreated fruit (control), 0.3 or $0.6 \mathrm{mM}$ thymol and 2.5 or $5 \mathrm{~g} / \mathrm{L}$ chitosan, then air dried. Fruits of each treatment packed in perforated punnets $(500 \mathrm{~g})$, each 6 punnets were packed in one plastic box $(40 \mathrm{~cm} \mathrm{X}$ $25 \mathrm{~cm} \mathrm{X} 15 \mathrm{~cm})$ as a replicate. The treatments were arranged in a randomized complete block design (RCBD) in a cold storage room at $0^{\circ} \mathrm{C}$ and $85-90 \%$ $\mathrm{RH}$ for one month. Ten fruits per replicate were taken before storage to determine the initial fruit quality. Samples of 3 replicates per treatment were taken weekly intervals to follow up the fruit quality and storability attributes after 2 days at room temperature as shelf-life.

\section{Fruit physical and chemical quality attributes}

Fruit firmness was determined using a fruit texture analyzer (Texturepro CT V1.2, Brookfield) with $2.5 \mathrm{~cm}$ flat tip at a speed of $2 \mathrm{~mm} / \mathrm{S}$. The fruit was compressed to a depth of $5 \mathrm{~mm}$ and compression force was expressed in Newtons (N). For soluble solids content (SSC), the flesh of five figs was pressed through cheesecloth with a hand press to obtain a composite juice sample (Crisosto et al., 2010). The juice was used for determination of SSC with a digital refractometer (ATAGO, mod. N$1 \mathrm{E}$, Japan) and expressed as percentages. The sugar extraction was carried out by using ten grams of well mixed fruit flesh tissues, using distilled water according to Loomis and Shull (1937). Reducing and total reducing sugars then determined by Fehling's test for reducing sugars and the inversion of the non-reducing sugars were done according to (AOAC, 2000). Non-reducing sugars were calculated by subtracting reducing sugars from total reducing sugars. One gram of fig flesh was homogenized in $25 \mathrm{ml}$ of $80 \%$ ethanol for phenolic compounds extraction at $25{ }^{\circ} \mathrm{C}$ for $15 \mathrm{~min}$, then filtered, and determined using Folin-Denis reagent according to Moyo et al., (2010). A standard curve of gallic acid was used for quantifying the total phenolic content, and data expressed as $\mathrm{mg} / 100 \mathrm{~g}$ fruit fresh weight according to Singleton and Rossi (1965).

\section{Fruit storability:}

Fruit storability was expressed as the percentage of fruit weight loss and decay incidence as well as fruit shriveling. Initial weight of 3 punnets per replicate was recoded then reweighted periodically at fruit sampling dates throughout the experiment period. Weight loss percentage was calculated as follow: Weight loss $(\%)=\left[\left(\mathrm{W}_{0^{-}}\right.\right.$ $\left.\left.\mathrm{W}_{1}\right) / \mathrm{W}_{0}\right] \times 100$ (where $\mathrm{W}_{0}$ is the initial weight and $\mathrm{W}_{1}$ is the weight measured at sampling date). The decay and shriveling were determined by calculating the weight of decayed or shriveled figs at the sampling date and expressed as a percentage of total figsweight.

Decay or shriveling $(\%)=\frac{\text { weight of decayed or shriveled figs }}{\text { Total figs weight }} \times 100$

Fruit decay was determined as percentage of decay incidence and transformed, using arcsine transformation to fit for analysis of variance. Total quantitative losses of fig fruits was calculated by summation the percentages of the unmarketable figs (decay and shriveling) + weight loss percent. The treatment ended when the total quantitative losses reached up to $25-30 \%$.

\section{Statistical analysis}

The treatments were arrangedin a randomized complete block design (RCBD), data were statistically analyzed and means were compared using LSD procedure at 5\% level of probability according to Gomez and Gomez (1984). The 
statistical analysis was done using SAS ver. 9.3, 2007.

\section{RESULTS AND DISCUSSION}

\section{Fruit physical and chemical quality attributes}

Results presented in Table (1), showed that, chitosan treatments at 2.5 or $5 \mathrm{~g} / \mathrm{L}$ significantly maintained fruit firmness, as they recorded higher significant compress force than control in both seasons and thymol at $0.3 \mathrm{mM}$ in the second season, after 1 week of cold storage +2 days at room temperature. The differences among thymol concentrations and control on compress force were not significant in 2018 year. After 2 weeks cod cold storage, the higher compress force was found with figs treated by chitosan at both levels, while fruit treated with chitosan at $5 \mathrm{~g} / \mathrm{L}$ was markedly firmer than thymol at both levels in both seasons (Table 2). The same result was noticed after 3 weeks of storage in 2017 year, however no significant differences were observed among all treatments in 2018 season (Table 3 ).

Postharvest chitosan and thymol treated figs had significantly higher SSC than those of control after 1 week of cold storage +2 days at room temperature in both seasons, except with thymol at $0.3 \mathrm{mM}$ in 2018 year (Table1). Results also revealed that chitosan at 2.5 or $5 \mathrm{~g} / \mathrm{L}$ significantly maintain the higher SSC percent than thymol at $0.3 \mathrm{mM}$ up to three weeks of cold storage in 2017 year, and with both thymol levels in the second season (Tables 2 and 3).

Concerning the effect of postharvest thymol and chitosan treatments on fruit total phenolic content, results in Table 1 , refer to thymol and chitosan treatments at both levels significantly maintained higher phenolic content than control after 1 week in both seasons. Figs treated with chitosan at $5 \mathrm{~g} / \mathrm{L}$ contained higher significant phenolic content than those treated with thymol at $0.3 \mathrm{mM}$ and chitosan at $2.5 \mathrm{~g} / \mathrm{L}$ in both seasons (Table 2). Meanwhile, no significant differences were noticed among all treatments in both seasons after 3 weeks (Table 3 ).

Regarding to fruit sugars content,the results in treatments significantly maintained higher total and non-reducing sugars than control after 1 week of cold storage +2 days at room temperature in both seasons, except with thymol treatments in 2018 year. While sugars content after 2 weeks of cold storage. The data in Table (2), revealed that chitosan treatments maintained higher sugars content in both seasons. However, chitosan at $5 \mathrm{~g} / \mathrm{L}$ had higher significant total sugars than thymol treatments at both levels in the two seasons, and also reducing and non-reducing sugars in 2018 year only. On the other hand, no significant effect was found among all treatments on reducing and non-reducing sugars in 2017 year.

Results in Table (3), represented that both chitosan levels had higher significant total sugars percent in both seasons. Meanwhile, both chitosan levels and thymol at $0.6 \mathrm{mM}$ were significantly higher on reducing sugars than thymol at $0.3 \mathrm{mM}$ in 2017 year. However, figs treated with chitosan at 5 $\mathrm{g} / \mathrm{L}$ was significantly higher than both thymol treatments on reducing sugars in 2018 year and nonreducing sugars in both seasons.

All in all, chitosan treated fruits had high or maintained the SSC, Compress force, phenolic contents as well as total sugars. These results could be due to reduction of deterioration and degradation reactions by chitosan coating film. These findings are in line with Seehanam et al. (2010) which reported that chitosan significantly slow down the respiration rate of 'Sai Nam Phueng' Tangerine by modifying the fruit internal atmosphere. As will known the postharvest consumption of sugars and organic acids as substrates for respiratory metabolism will reduce as respiration process and oxidative stresses decreased.

\section{Fruit storability}

Chitosan treatments at 2.5 and $5 \mathrm{~g} / \mathrm{L}$ significantly reduced fruit weight loss percent throughout the experiment period up to 3 weeks as compared with the rest treatments in both seasons, except between chitosan at $2.5 \mathrm{~g} / \mathrm{L}$ and both thymol treatments after one week in 2017 year only (Figure 1).

Table 1: Effect of postharvest chitosan and thymol treatments on SSC, compress force, total phenols, total, reducing and non-reducing sugars of Sultani fig after 1 week of cold storage at $0^{\circ} \mathrm{C}+2$ days at room temperature in 2017 and 2018.

\begin{tabular}{|c|c|c|c|c|c|c|c|c|c|c|c|c|}
\hline \multirow[t]{2}{*}{ Treatments } & \multicolumn{2}{|c|}{ SSC (\%) } & \multicolumn{2}{|c|}{$\begin{array}{l}\text { Compress } \\
\text { force }(N)\end{array}$} & \multicolumn{2}{|c|}{$\begin{array}{c}\text { Total phenols } \\
\text { (mg/100g FW) }\end{array}$} & \multicolumn{2}{|c|}{$\begin{array}{c}\text { Total sugars } \\
(\%)\end{array}$} & \multicolumn{2}{|c|}{$\begin{array}{c}\text { Reducing } \\
\text { sugars (\%) }\end{array}$} & \multicolumn{2}{|c|}{$\begin{array}{c}\text { Non-reducing } \\
\text { sugars }(\%)\end{array}$} \\
\hline & 2017 & 2018 & 2017 & 2018 & 2017 & 2018 & 2017 & 2018 & 2017 & 2018 & 2017 & 2018 \\
\hline Control & 15.20 & 15.00 & 0.65 & 0.75 & 325.0 & 303.3 & 11.22 & 11.12 & 10.03 & 9.84 & 1.19 & 1.28 \\
\hline Thymol $0.3 \mathrm{mM}$ & 15.47 & 15.20 & 0.94 & 0.81 & 364.3 & 343.3 & 11.88 & 11.51 & 9.93 & 9.83 & 1.95 & 1.68 \\
\hline Thymol $0.6 \mathrm{mM}$ & 15.60 & 15.33 & 0.92 & 0.87 & 366.6 & 380.0 & 11.83 & 11.45 & 9.91 & 9.99 & 1.92 & 1.46 \\
\hline Chitosan $2.5 \mathrm{~g} / \mathrm{L}$ & 15.63 & 15.47 & 0.97 & 0.99 & 365.4 & 360.0 & 11.95 & 11.79 & 10.00 & 9.98 & 1.95 & 1.81 \\
\hline Chitosan $5 \mathrm{~g} / \mathrm{L}$ & 15.70 & 15.67 & 0.98 & 0.97 & 371.5 & 390.0 & 12.08 & 11.82 & 10.04 & 9.95 & 2.04 & 1.87 \\
\hline L.S.D. at 0.05 & 0.21 & 0.27 & 0.14 & 0.14 & 29.5 & 27.8 & 0.52 & 0.47 & 0.36 & 0.20 & 0.47 & 0.46 \\
\hline
\end{tabular}


(a)

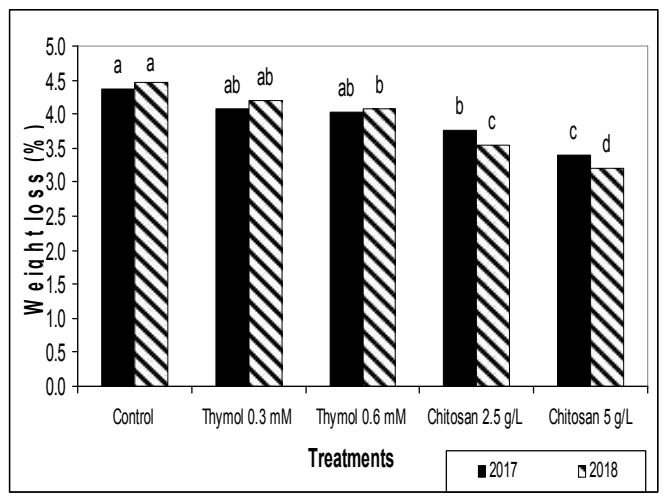

(c)

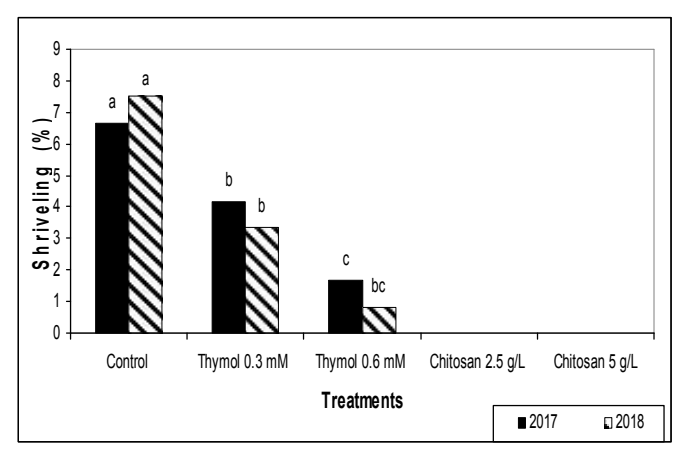

(b)

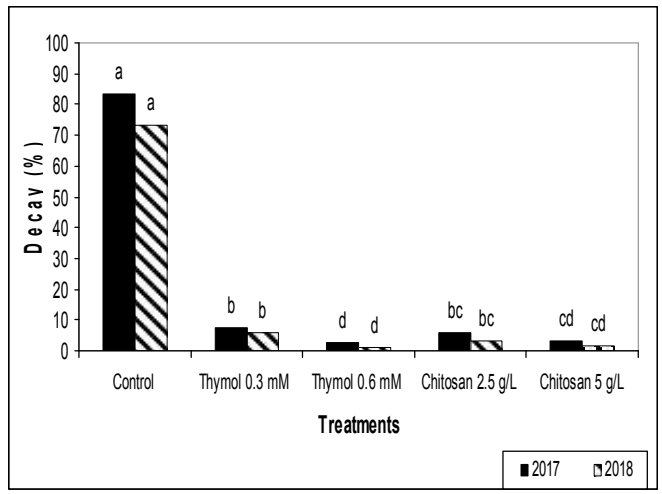

(d)

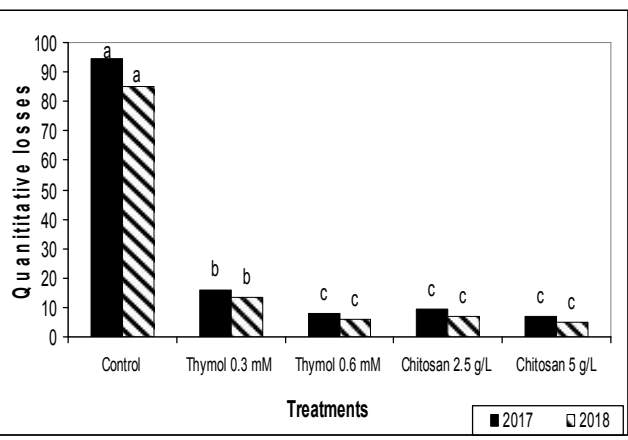

Figure 1: Effect of postharvest thymol and chitosan applications on percent of weight loss, decay, shriveling and total quantitative losses on Sultani fig after 1 week at $0^{\circ} \mathrm{C}+2 \mathrm{~d} @ \mathrm{RT}$ in 2017 and 2018. Means followed by same letters in the same season are not significantly different at $(P<0.05)$.

Table 2: Effect of postharvest chitosan and thymol treatments on SSC, compress force, total phenols, total, reducing and non-reducing sugars of Sultani fig after 2 weeks of cold storage at $0^{\circ} \mathrm{C}+2$ days at room temperature in 2017 and 2018.

\begin{tabular}{lcccccccccccc}
\hline \multirow{2}{*}{ Treatments } & \multicolumn{2}{c}{ SSC (\%) } & \multicolumn{2}{c}{$\begin{array}{c}\text { Compress } \\
\text { force (N) }\end{array}$} & \multicolumn{2}{c}{$\begin{array}{c}\text { Total phenols } \\
\text { (mg/100g FW) }\end{array}$} & \multicolumn{2}{c}{$\begin{array}{c}\text { Total sugars } \\
(\mathbf{\%})\end{array}$} & \multicolumn{2}{c}{$\begin{array}{c}\text { Reducing } \\
\text { sugars (\%) }\end{array}$} & $\begin{array}{c}\text { Non-reducing } \\
\text { sugars (\%) }\end{array}$ \\
\cline { 2 - 14 } & $\mathbf{2 0 1 7}$ & $\mathbf{2 0 1 8}$ & $\mathbf{2 0 1 7}$ & $\mathbf{2 0 1 8}$ & $\mathbf{2 0 1 7}$ & $\mathbf{2 0 1 8}$ & $\mathbf{2 0 1 7}$ & $\mathbf{2 0 1 8}$ & $\mathbf{2 0 1 7}$ & $\mathbf{2 0 1 8}$ & $\mathbf{2 0 1 7}$ & $\mathbf{2 0 1 8}$ \\
\hline Thymol $0.3 \mathrm{mM}$ & 15.13 & 15.07 & 0.74 & 0.68 & 249.9 & 266.7 & 10.68 & 10.58 & 9.48 & 9.34 & 1.20 & 1.23 \\
\hline Thymol $0.6 \mathrm{mM}$ & 15.40 & 15.10 & 0.75 & 0.65 & 264.8 & 283.3 & 10.74 & 10.70 & 9.53 & 9.41 & 1.22 & 1.29 \\
\hline Chitosan $2.5 \mathrm{~g} / \mathrm{L}$ & 15.47 & 15.33 & 0.82 & 0.80 & 252.2 & 260.0 & 11.26 & 11.04 & 9.69 & 9.59 & 1.58 & 1.45 \\
\hline Chitosan $5 \mathrm{~g} / \mathrm{L}$ & 15.60 & 15.47 & 0.87 & 0.82 & 293.7 & 303.3 & 11.59 & 11.41 & 9.77 & 9.63 & 1.82 & 1.78 \\
\hline L.S.D. at 0.05 & 0.24 & 0.21 & 0.12 & 0.14 & 30.1 & 29.8 & 0.61 & 0.38 & 0.31 & 0.22 & 0.78 & 0.47 \\
\hline
\end{tabular}

Table 3: Effect of postharvest chitosan and thymol treatments on SSC, compress force, total phenols, total, reducing and non-reducing sugars of Sultani fig after 3 weeks of cold storage at $0^{\circ} \mathrm{C}+2$ days at room temperature in 2017 and 2018.

\begin{tabular}{|c|c|c|c|c|c|c|c|c|c|c|c|c|}
\hline \multirow[t]{2}{*}{ Treatments } & \multicolumn{2}{|c|}{$\operatorname{SSC}(\%)$} & \multicolumn{2}{|c|}{$\begin{array}{l}\text { Compress } \\
\text { force (N) }\end{array}$} & \multicolumn{2}{|c|}{$\begin{array}{l}\text { Total phenols } \\
\text { (mg/100g FW) }\end{array}$} & \multicolumn{2}{|c|}{$\begin{array}{c}\text { Total sugars } \\
(\%)\end{array}$} & \multicolumn{2}{|c|}{$\begin{array}{c}\text { Reducing } \\
\text { sugars (\%) }\end{array}$} & \multicolumn{2}{|c|}{$\begin{array}{c}\text { Non-reducing } \\
\text { sugars }(\%)\end{array}$} \\
\hline & 2017 & 2018 & 2017 & 2018 & 2017 & 2018 & 2017 & 2018 & 2017 & 2018 & 2017 & 2018 \\
\hline Thymol $0.3 \mathrm{mM}$ & 14.60 & 14.47 & 0.55 & 0.49 & 116.8 & 140.0 & 9.74 & 9.63 & 8.73 & 8.66 & 1.01 & 0.97 \\
\hline Thymol $0.6 \mathrm{mM}$ & 14.80 & 14.53 & 0.53 & 0.50 & 128.4 & 153.3 & 10.09 & 9.81 & 9.14 & 9.00 & 0.95 & .81 \\
\hline Chitosan $2.5 \mathrm{~g} / \mathrm{L}$ & 15.33 & 14.93 & 0.67 & 0.56 & 118.0 & 133.3 & 10.79 & 10.47 & 9.36 & 9.24 & 1.43 & 1.23 \\
\hline Chitosan $5 \mathrm{~g} / \mathrm{L}$ & 15.40 & 15.00 & 0.72 & 0.58 & 129.5 & 160.0 & 11.24 & 10.83 & 9.47 & 9.27 & 1.77 & 1.56 \\
\hline L.S.D. at 0.05 & 0.56 & 0.38 & 0.11 & 0.13 & 14.9 & 30.8 & 0.57 & 0.43 & 0.34 & 0.25 & 0.65 & 0.54 \\
\hline
\end{tabular}




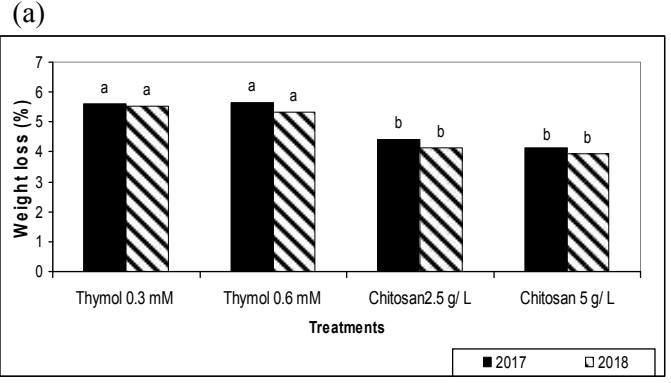

(c)

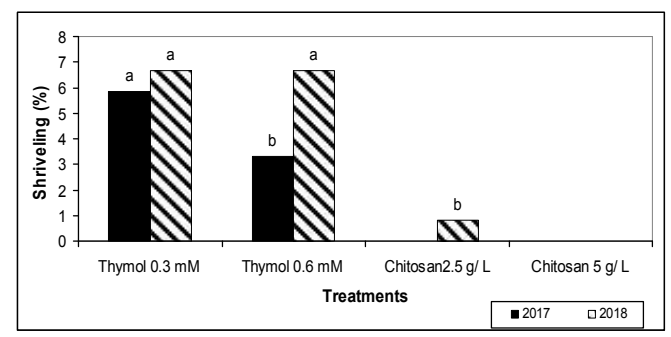

(b)

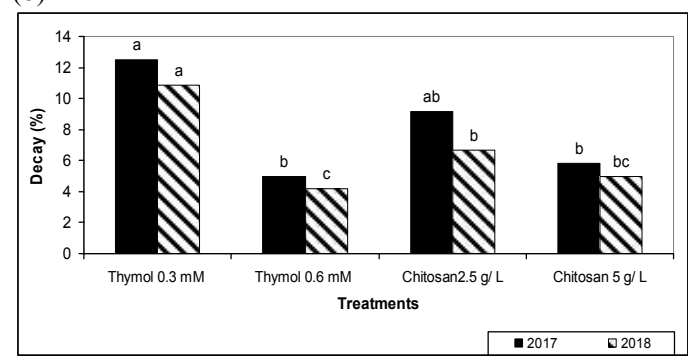

(d)

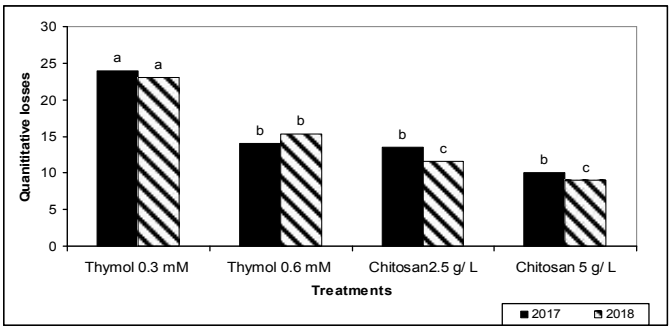

Figure 2: Effect of postharvest thymol and chitosan applications on percent of weight loss, decay, shriveling and total quantitative losses on Sultani fig after 2 week at $0^{\circ} \mathrm{C}+2 \mathrm{~d} @ \mathrm{RT}$ in 2017 and 2018. Means followed by same letters in the same season are not significantly different at $(P<0.05)$.

(a)

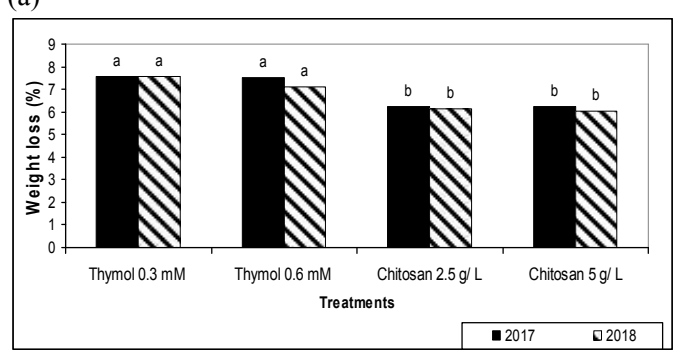

(c)

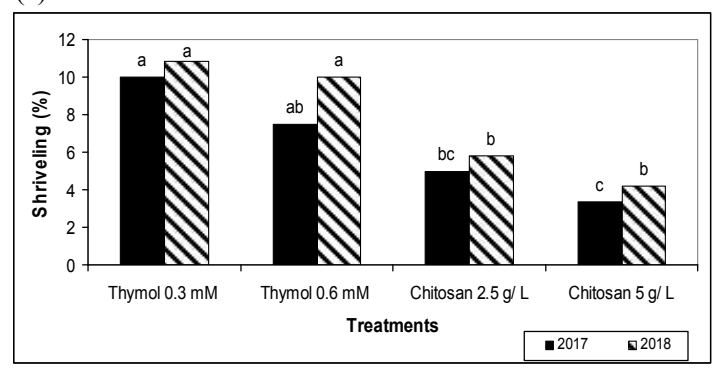

(b)

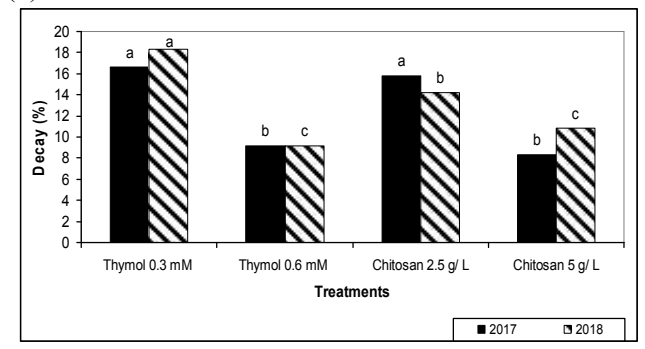

(d)

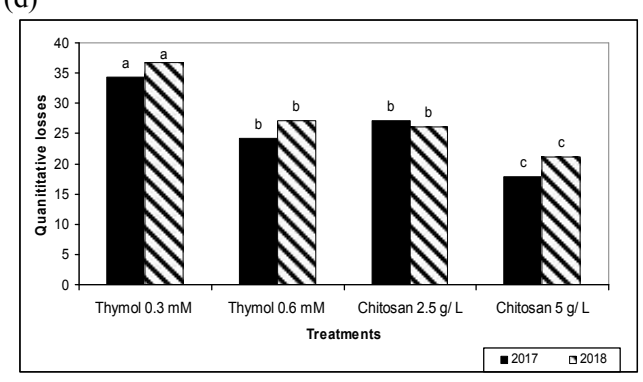

Figure 3: Effect of postharvest thymol and chitosan applications on percent of weight loss, decay, shriveling and total quantitative losses on Sultani fig after 3 week at $0^{\circ} \mathrm{C}+2 \mathrm{~d} @ \mathrm{RT}$ in 2017 and 2018. Means followed by same letters in the same season are not significantly different at $(P<0.05)$. 
Moreover, the higher concentration of chitosan is more efficient for reduction of weight loss after 1 week of cold storage, while the differences among chitosan or thymol levels were not significant after 2 or 3 weeks of cold storage in both seasons (Figures 2 and 3 ).

The decay incidence severely reduced by postharvest thymol and chitosan treatments after 1 week under cold storage +2 days at room temperature in both seasons (Figure 1). No significant differences on decay percent were noticed among thymol and chitosan treatments in both seasons, except with thymol at $0.6 \mathrm{mM}$, which significantly reduced decay incidence than thymol at $0.3 \mathrm{mM}$ and chitosan at $2.5 \mathrm{~g} / \mathrm{L}$ in 2017 . Results in Figure (2), represented that thymol at $0.6 \mathrm{mM}$ and chitosan at $5 \mathrm{~g} / \mathrm{L}$ significantly reduced decay percent as compared with thymol at $0.3 \mathrm{mM}$ after storage for 2 weeks in 2017 and 2018 years. Furthermore, the higher levels of both thymol and chitosan had lower significant decay percent than lower levels after cold storage for 3 weeks, in both seasons Figure (3).

Regarding to shriveling percent results reveled thatall treatments significantly reduced shriveling percent as compared with control after 1 week in both seasons (Figure 1). While, the lowest shriveling percent was found with both chitosan levels in both seasons, and thymol at $0.6 \mathrm{mM}$ in 2017 year. Moreover, chitosan treatments recorded the lowest significant shriveling percent up to 3 weeks of cold storage +2 days at room temperature in both seasons, but the difference among chitosan at $2.5 \mathrm{~g} / \mathrm{L}$ and thymol at $0.6 \mathrm{mM}$ after 3 weeks was not significant in 2017 year (Figure 3).

Postharvest treatments with chitosan and thymol at both levels significantly reduced the quantitative losses than control after the first week of storage (Figure 1). But the lowest percent of quantitative losses was occurred with chitosan at 2.5 or $5 \mathrm{~g} / \mathrm{L}$ and thymol at $0.6 \mathrm{mM}$ in both seasons. Moreover, both chitosan levels and thymol at 0.6 $\mathrm{mM}$ markedly reduced the quantitative losses as compared with thymol at $0.3 \mathrm{mM}$ after 2 weeks of cold storage (Figure 2). In addition, chitosan at 5 $\mathrm{g} / \mathrm{L}$ had the lowest significant quantitative losses, followed by chitosan at $2.5 \mathrm{~g} / \mathrm{L}$ and thymol at 0.6 $\mathrm{mM}$, while thymol at $0.3 \mathrm{mM}$ had the highest percent of postharvest losses in both seasons.

Chitosan treatments markedly reduced figs weight loss and shriveling percentages in the two experimental seasons, these results could be due to formation ofchitosan semi-permeable film, modifying the endogenous gases exchange mainly water vapor, $\mathrm{CO}_{2}, \mathrm{O}_{2}$ and $\mathrm{C}_{2} \mathrm{H}_{4}$, which reduced water loss, respiration rate and subsequently retard fruit ripening and senescence by (Cosme Silva, et al., 2017).
Both chitosan and thymol treatments controlled postharvest decay incidence. The effect of thymol on reduction of decay may be due to inhibition of conidia germination and mycelial growth. This results are in line with (Luiet al., 2002), they reported that thymol treatment was effective on postharvest decrease of brown rot on apricots as a result of mycelial growth inhibition of Monlinia fructicola. Furthermore, thymol changed the morphological and internal structure of M. fructicola conidia, casing shrunken shapes and collapsed protoplasts. Moreover, thymol efficiently controlled postharvest gray mold decay on sweet cherries (Chu et al., 1999).

\section{CONCLUSION}

From previous findings we can summarize that the postharvest life of fresh Sultani figs can be extended up to 3 weeks and postharvest losses significantly reduced by chitosan and thymol treatments with cold storage at $0^{\circ} \mathrm{C}$ and $90 \% \mathrm{RH}$. Both chitosan and thymol treatments controlled postharvest decay incidence. Chitosan treatments significantly reduced fruit weight loss and shriveling up to 3 weeks. Thymol and chitosan applications were very effective on controlling decay incidence and quantitative losses after 1 week of cold storage $+2 \mathrm{~d}$ at room temperature. Chitosan treatments markedly maintained higher figs firmness, SSC, phenolic content, total and non-reducing sugars. This results showed that chitosan and thymol are promising safe alternatives to control postharvest diseases and increase marketability of fresh Sultani figs. More experiments are needed to determine the efficiency of wide spectrum of essential oils and their combinations with chitosan.

\section{REFERENCES}

A.O.A.C. 2000. Official Methods of Analysis of the Association of Official Analytical Chemists. $17^{\text {th }}$ ed. Washington, DC, USA., pp 578.

AitBarka, E., P.Eullaffroy, C.Cle'ment, and G.Vernet. 2004. Chitosan improves development, and protects Vitis vinifera L. against Botrytis cinerea. Plant Cell Reports, 22: 608-614.

Chu, C.L., W.T. Liu, T. Zhou and R. Tsao. 1999. Control of postharvest gray mold rot of modified atmosphere packaged sweet cherries by fumigation with thymol and acetic acid. Can. J. Plant Sci., 79(4): 685-689.

Colelli, G., F.G. Mitchell, and A.A. Kader. 1991. Extension of Postharvest Life of 'Mission' Figs by CO2-enriched Atmospheres. Hort. Sci., 26(9):1193-1195. 
Cosme Silva, G.M., W.B.Silva, D.B.Medeiros, A. R. Salvador, M. H. Cordeiro, N.M.Silva, D. B. Santana, and G.P. Mizobutsia. 2017. The chitosan affects severely the carbon metabolism in mango (Mangifera indica $\mathrm{L}$. cv. Palmer) fruit during storage. Food Chem. 237: $372-378$

Coviello, R., W. Bentley, T.Michailides, L. Ferguson, and B.Westerdahl. 2009. UC Statewide Integrated Pest Management Program. Pest management guidelines: fig. Publication 3447.

Crisosto, C. and A.A. Kader. 2007. Figs. Postharvest quality maintenance guidelines. Postharvest information for fruits and nuts. Available from: http://www.uckac.edu/ postharv [Accessed 8 November 2007].

Crisosto, C.H., D. Garner, V. Bremer, E. Stover and L. Ferguson. 2007. Investigating the potential of sulfur dioxide $\left(\mathrm{SO}_{2}\right)$ applications for decay control of brown and yellow color figs. Available from: http://groups.ucanr.org/freshfi g/index.cfm [Accessed 25 October 2007].

Crisosto, C.H., V. Bremer, L. Ferguson, and G. M. Crisosto. 2010. Evaluating Quality Attributes of Four Fresh Fig (Ficus carica L.) Cultivars Harvested at Two Maturity Stages. Hort.Sci. 45(4):707-710.

Doster, M.A. and T.J.Michailides. 2007. Fungal decay of first-crop and main-crop figs. Plant Dis. 91: 1657-1662.

Doster, M.A., T.J.Michailides, and D.P. Morgan. 1996. Aspergillus species and mycotoxins in figs from California orchards. Plant Dis. 80: 484-489.

El Ghaouth, A., J.Arul, J.Grenier, and A.Asselin. 1992. Antifungal activity of chitosan on two postharvest pathogens of strawberry fruits. Phytopathology, 82: 398-402.

FAOStat. 2017. FAO statistics database on the World Wide Web, 2017. http://apps.fao.org/.

Geransayeh, M., S. Sepahvand, V. Abdossi and R.A. Nezhad. 2015. Effect of thymol treatment on decay, postharvest life and quality of strawberry (Fragaria ananassa) Fruit cv. 'Gaviota. International Journal of Agronomy and Agricultural Research. 6 (4): 151-162.

Gomez, K.A. and A.A. Gomez. 1984. Statistical procedures for agricultural research. $2^{\text {nd }} \mathrm{Ed}$. John Wiley and Sons. New York.

Jain, S.K.. 1985. Medicinal plants. Natl. Book Trust, New Delhi.
Kalemba, D. and A. Kunicka. 2003. Antibacterial and antifungal properties of essential oils. Curr Med Chem. 10(10): 813-829.

Liu, W.T., C.L. Chu and T. Zhou. 2002. Thymol and acetic acid vapors reduce postharvest brown rot of apricots and plums. Hort. Sci., 37:151-156.

Loomis, W.E. and C.A. Shull. 1937. Methods in plant physiology. MC. Grow. Hill Book Co. Inc. New York.

Mansour, F., U. Ravid and E. Putievsky. 1986. Studies of essential oils isolated from 14 species of Labiatae on the carimine spider mint, Tetranychus cinnabarinus. Phytoparasitica, 14: 137-142.

Meng, X.H., B.Q. Li, J.Liu, and S.P. Tian. 2008. Physiological responses and quality attributes of table grape fruit to chitosan preharvest spray and postharvest coating during storage. Food Chemistry, 106: 501-508.

Molinu, M.G., T.Venditti, A. Dore, G.D.Hallewin and A.Serusi. 2006. Postharvest decay reduction of fi $\mathrm{g}$ fruit (Ficus carica) by hot water sodium carbonate solution dip. Commun Agric. Appl. Biol. Sci., 71: 923928.

Morton, J.F. 2000. Fruits of warm climates. Fig. Ficus carica. Purdue University. New CROP. Available from: http://www.hort.purdue.edu/newcrop/default. html 25[Accessed November 2007].

Moyo, M., A.R.Ndhlala, J.F. Finnie, and J. Van Staden. 2010. Phenolic composition, antioxidant and acetylcholinesterase inhibitory activities of Scleroc aryabirrea and Harpephyllum caffrum (Anacardiaceae) extracts. Food Chem. 123: 69-76.

Olivas, G.I. and G.V. Barbosa-Cánovas. 2005. Edible coatings for fresh-cut fruits. Crit. Rev. Food Sci. Nutr. 45: 7-8.

Romanazzi, G., F.Nigro, A.Ippolito, D.Di Venere, and M.Salerno. 2002. Effects of pre- and postharvest chitosan treatments to control storage grey mould of table grapes. Journal of Food Science, 67: 1862-1867.

Seehanam, P., D. Boonyakiat, and N. Rattanapanone. 2010. Physiological and physicochemical responses of 'Sai Nam Phueng' tangerine to commercial coatings. Hort. Sci., 45: 605-609.

Singleton, V.L., and J.A. Rossi. 1965. Colorimetry of total phenolics with phosphomolybdicphosphotungisticacid reagents. Am. J. Enol. Vitic. 16: 144-158.

Slavin, J.L. 2006. Figs: Past, Present and Future. Nutr. Today 41:180-184. 
Spadaro, D. and M.L. Gullino. 2014. Use of essential oils to control postharvest rots on pome and Stone fruit. Postharvest Pathology. 7: 101-110.

Tripathi, P. and N.K. Dubey. 2004. Exploitation of natural products as alternative strategy to control post-harvest fungal rotting of fruits and vegetables. Postharvest Biol. Technol., 32: 235-245.
Veberic, R., M. Colaric, and F. Stampar. 2008. Phenolic acids and flavonoids of fig fruit (Ficus carica L.) in the northern Mediterranean region. Food Chem.106:153157.

Wang L., H, Wu, G. Qin and X. Meng. 2014. Chitosandisrupts Penicillium expansum and controlspostharvest blue mold of jujube fruit. Food Control. 41: 56-62.

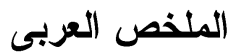

\section{تقليل الفاقد في ثمار التين السلطاني أثناء التسويق بواسطة الغمس في الثيمول والثيتوزان}

\author{
يحيى صلاح مصطفى، أسلام محمد البرى ونبيل ثابت مصطفى \\ قسم الفاكهة، كلية الزر اعة، جامعة الأسكندرية، الأسكندرية، دصر
}

القابلية العالية للتلف و أمر اض مابعد الحصـاد تحد من تخزين و تسويق ثمار التين الطازجة. الهدف مـن هـــه

الدراسة هو تقييم تأثيرمعاملات الغس بعد الحصاد بالثيتوزان و الثثيمول على الأعفان وجودة ثمار التين الـسلطانى.

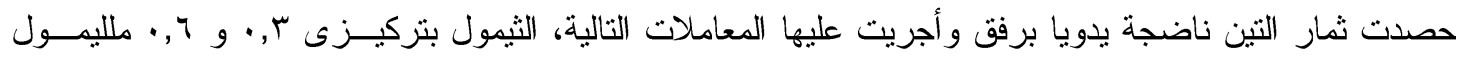

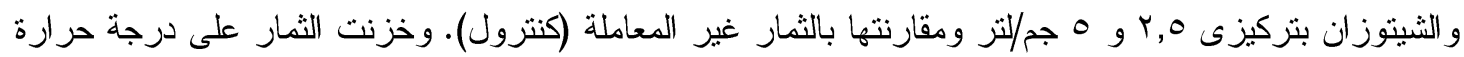

صفر مئوى ورطوبة نسبية 01-، و \%، وأخذت عينات أسبو عيا لقياس خصائص الجودة و القدرة التخزينية للتثــار

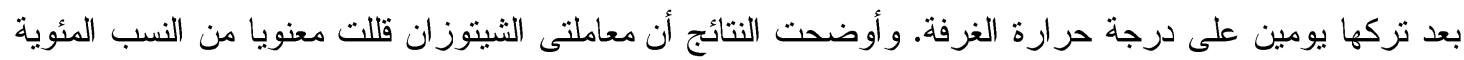

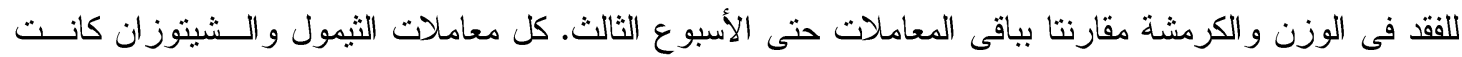

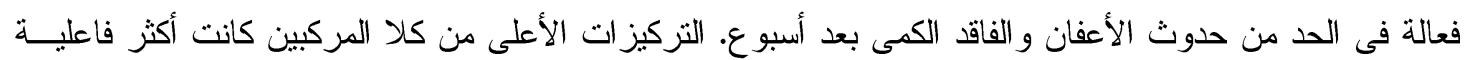

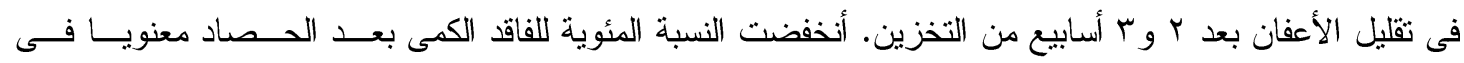

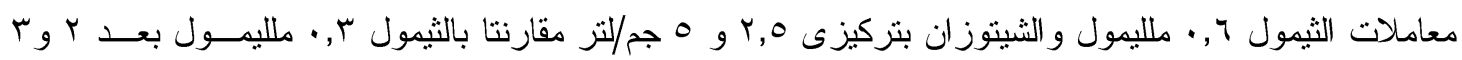

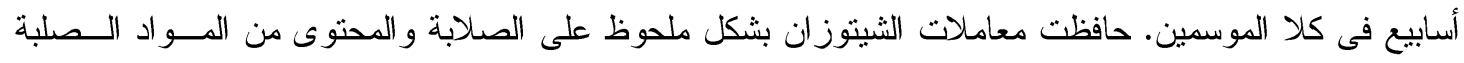

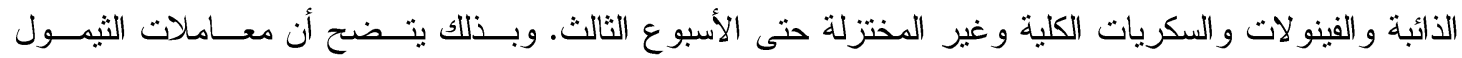

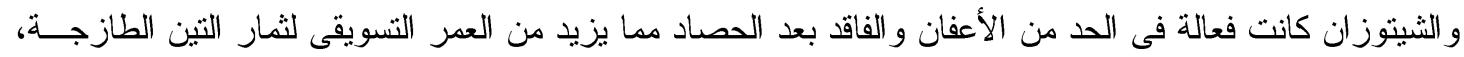
إلا أن الثيتوزان كان الأكثر فاعلية. 